\title{
Candidate Coethnicity, Rural/Urban Divides, and Partisanship in Africa
}

Journal Title

$X X(X): 2-27$

(C) The Author(s) 2016

Reprints and permission:

sagepub.co.uk/journalsPermissions.nav DOI: 10.1177/ToBeAssigned www.sagepub.com/

\section{Robin Harding ${ }^{1}$ and Kristin Michelitch ${ }^{2}$}

\begin{abstract}
Why do some citizens in new democracies attach to parties while other do not? We investigate the determinants of partisanship in Africa by theorizing the role of parties' group mobilization tactics and testing our arguments alongside existing explanations from new democracies. First, using original data on candidate ethnicity, we evaluate a debate as to whether coethnicity with presidential and/or vice-presidential candidates is associated with greater partisanship. Contrary to traditional wisdom, we find no continent-wide relationship - prominently-studied cases (e.g., Kenya, Ghana) may be falsely overgeneralized. Second, we propose that partisanship is more likely among rural citizens. We find robust, continent-wide support for this relationship, which we show is partially driven by citizens' links to traditional authorities, who often act as opinion leaders and/or brokers for parties. As in other new democracies, partisanship is positively associated with experience with multiparty democracy, the electoral cycle, age, male gender, and education.
\end{abstract}

\section{Keywords}

Partisanship, Africa, Ethnicity, Urban/Rural Divide 


\section{Introduction}

In new democracies, partisanship has been found to be associated with political participation (Brader and Tucker 2001; Conroy-Krutz et al. 2016), biased information processing (Carlson 2016), and discrimination between citizens (Michelitch 2015). Thus, a growing scholarship, mostly focusing on Eastern Europe and Latin America, examines why some individuals attach to parties, while others do not. Existing work has broadened theory to include such factors as electoral cycle effects (Michelitch and Utych 2018), experience with democracy (Brader and Tucker 2008), and party institutionalization (Dalton and Weldon 2007). In this study, we investigate the determinants of partisanship in sub-Saharan Africa (hereafter Africa). We expand on previous work by theorizing the role of parties' group mobilization tactics in this context and testing our arguments alongside existing theory.

Existing literature underscores how parties commonly endeavor to mobilize existing groups of citizens as loyal partisans, rather than individual citizens, to lower the costs of campaigning (Lipset and Rokkan 1967; Huntington 1968). When a party mobilizes a group with strong, clear signals of representational "fit," partisan attachments are facilitated (Lupu 2013; Green et al. 2002). Cross-pressuring by multiple parties increases internal uncertainty regarding true partisan positions and external discomfort with publicly taking partisan sides to avoid social conflict (Mutz 2002). Further, expressions and actions supporting a party further engenders and mutually-reinforces a sense of commitment, loyalty, and ultimately attachment to a party because individuals seek psychological conformity between behavior, expressions and identity (Brader and Tucker 2001; Michelitch and Utych 2018). Which groups are effectively mobilized to attach to political parties is, of course, context specific.

In African democracies, distributive politics largely revolves around geographic targeting of "valence" public goods (e.g., schools, roads) to particular communities rather than a left-right ideological continuum

\footnotetext{
${ }^{1}$ University of Oxford, UK

${ }^{2}$ Vanderbilt University, USA
}

Corresponding author:

Kristin Michelitch, Vanderbilt University, USA

Email: kristin.michelitch@vanderbilt.edu 
(Bleck and van de Walle 2012). We argue that such distributive politics leads parties to more effectively mobilize two types of groups, increasing those groups' propensity to attach to parties. First, the dominant wisdom holds that coethnicity with presidential and/or vice-presidential candidates mobilizes citizens toward a party by generating expectations of public goods targeting and "expressive utility" (Ferree 2006; Carlson 2015; Bates 1974; Horowitz 1985). Stated more broadly, descriptive representation of one's identity group can motivate beliefs in enhanced substantive and symbolic representation (Pitkin 1967). Horowitz (2017) argues that having such a coethnic candidate facilitates citizens' identification of partisan congruence because a clear, credible signal of belonging to a party's core constituency exists, while other groups are courted by multiple parties and become cross-pressured.

However, more recent scholarship emphasizes important reasons to doubt traditional wisdom. First, little marginal value of coethnicity with presidential and vice-presidential candidates may exist above and beyond other signals of inclusion necessary to build multi-ethnic winning coalitions (Arriola 2012; Ferree and Horowitz 2010). Second, ethnic groups may be too large and diffuse identity groups for parties to effectively mobilize citizens through mere coethnic descriptive representation (Koter 2013; Harris 2015). In many contexts, candidate coethnicity, and ethnicity in general, may simply be irrelevant in electoral politics (Bleck and van de Walle 2018). Finally, citizens may have other strategic considerations that divide loyalties — supporting different (and at times non-coethnic) candidates, especially in non-presidential elections (Ichino and Nathan 2013; Nathan 2016; Weghorst and Lindberg 2013; Conroy-Krutz 2013).

Second, scholars have noted how party mobilization differs starkly across the urban/rural divide (Lindberg 2010; Bratton et al. 2005; Bleck and van de Walle 2018). Urban citizens are cross-pressured on an individual level by multiple parties (Dulani et al. 2018; Resnick 2012). Diverse mixed partisan media further cross-pressure urban citizens (Moehler and Conroy-Krutz 2016). Ultimately, urban citizens are more difficult to effectively target to engender partisanship to a particular party (Ichino and Nathan 2013). By contrast, traditional village authorities have an unrivaled influence steering rural citizens towards their preferred party (Baldwin 2013; Koter 2013), sometimes mobilizing a village "bloc 
vote" in exchange for public service improvements from parties (Gottlieb and Larreguy 2018). The weak media environment tends to be limited in challenging such influence (Bleck and Michelitch 2018). Further, in the multiparty era, parties have shifted to favoring rural majorities with policy outputs, who are easier to target (Harding 2018; Bates and Block 2013). While urban cross-pressuring should dampen partisanship, clear, reinforcing signals of party fit in rural areas should facilitate partisanship.

To evaluate these arguments, we analyze data from 30 African countries using Afrobarometer Rounds 1-6 (1999-2015). Through archival work with additional coauthors, we generate an original dataset of presidential and vice presidential candidates' ethnicity from all major parties during this time period, which is joining a forthcoming larger dataset "African Leader and Candidate Ethnicity Dataset" with additional coauthors (Adida et al. 2020). To evaluate existing scholarly arguments, we leverage, and extend forward in time, datasets from Michelitch and Utych (2018), Weghorst and Bernhard (2014), Przeworski (2013), and Cruz et al. (2018).

The results both extend and challenge existing wisdom regarding African politics. We broaden existing work on candidate coethnicity, mostly centered on vote choice in case studies, by examining this phenomenon cross-nationally and focusing on partisan attachments. We find that coethnicity with a presidential and/or vice-presidential candidate is neither a significant determinant of partisanship across the region (according to many alternative codings and modeling specifications), nor significant conditional on a range of theoretically-motivated factors. This study thus joins others challenging the importance and straightforward impact of coethnicity with major party candidates for African politics. Indeed, Bleck and van de Walle (2018)'s new book on electoral politics across Africa underscores that ethnicity has in many cases unduly dominated scholarly discussion of political behavior in Africa. The prominence of candidate coethnicity from a few prominently studied cases - e.g., Ghana and Kenya - may be unjustifiably generalized to the continent as a whole.

Second, the data support the hypothesis that rural citizens are more likely to be partisan than urban citizens, ${ }^{1}$ as well as observable implications of a part of the argument: those reporting feeling closer to traditional authorities are more likely to be partisan. These results broaden our understanding of the consequences of urban/rural divisions in 
party mobilization tactics to partisanship, expanding existing knowledge of rural/urban divides in public goods provision, turnout, and the bloc vote (Baldwin 2013; Gottlieb and Larreguy 2018; Harding 2018).

Only certain theories stemming from partisanship theories in Eastern Europe and Latin America hold true in Africa. As elsewhere, a positive association exists between partisanship and experience with democracy, proximity to elections, male gender, age, and education. However, aspects of party systems found to be salient in these other regions (electoral volatility, party age, party fractionalization) have no relationship with partisanship in this context. This study thus contributes to comparative politics more generally in two ways: (a) by testing the external validity of existing partisanship theories in Africa, and (b) by expanding and testing theory to examine a class of arguments centered around parties' group mobilization tactics. Moving forward, comparativists studying partisanship in new democracies should incorporate context-specific group mobilization in their theories of partisanship alongside other determinants.

Finally, some scholars may question the importance of partisanship in Africa, labeling it as shallow, minimalist, or thin. We demonstrate its meaning by showing a strong relationship between partisanship and diverse acts of political and civic participation: partisans are more likely to raise issues to government authorities, attend community meetings, attend election rallies, attend election meetings, mobilize others to support a party (informally and formally), and turn out to vote.

\section{Partisanship in Africa}

Scholars of new democracies define partisanship as a party attachment where an individual "feels close to a political party" (Brader and Tucker 2001; Dalton and Weldon 2007). Given the relative newness of multiparty competition and party systems in Africa versus other regions (Bleck and van de Walle 2018), scholars studying advanced democracies may question the existence of partisanship. Joining Brader and Tucker (2001), we believe scholars often underestimate how quickly citizens attach to parties in new democracies. Indeed, leveraging AfroBarometer rounds 1-6 (1999-2015), AmericasBarometer 1-6 (2004-2014), and European Social Survey 1-5 (2002-2012) data, we find that the level of partisanship is relatively higher in Africa than other regions (Figure 1). Pooled together, 


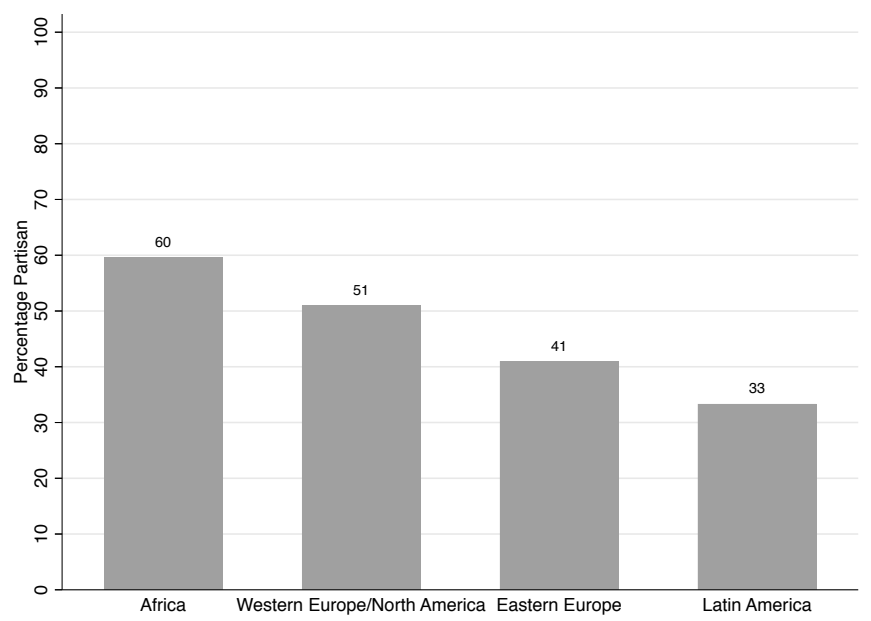

Figure 1. Percentage "close to a political party" from Afrobarometer Rounds 1-6, AmericasBarometer Rounds 1-6, and European Social Survey Rounds 1-5.

$60 \%$ of African citizens feel close to a party, compared to $51 \%$ in Western Europe \& North America, 41\% in Eastern Europe, and 33\% in Latin America (countries listed in Supplemental Information (SI) A).

\section{How Party Mobilization Engenders and Reinforces Partisanship}

Our theoretical and empirical focus in explaining the determinants of partisanship across Africa centers on how parties' group-mobilization tactics affect which groups of individuals within a country are more likely to be effectively mobilized to support, and attach to, a political party. A related literature examines why individuals attach to certain parties over others (e.g., Ferree and Horowitz (2010)), while in this study we seek to understand why some individuals develop partisanship towards any party whatsoever.

Seminal literature on party institutionalization in Western Europe (e.g., Lipset and Rokkan (1967); Huntington (1968)) emphasized party formation around dominant social group cleavages, focusing primarily on industrialized contexts where distributive politics often revolved around left-right class-based interests. Seeking to mobilize the largest number of citizens at the lowest cost where possible, parties endeavored to capture existing groups of citizens as loyal partisans, rather than individual 
citizens. Explanations for group-based mobilization, typically of urban worker or business interest groups, focused primarily on common interests and identity shared among group members, as well as vote brokerage by group leaders.

Contemporary partisanship literature describes key mechanisms through which party mobilization engenders and reinforces partisanship. Namely, strong, clear, and reinforcing signals of one's fit with a "party brand"for whom (or what) a party stands_facilitates partisanship (Lupu 2013), especially where individuals can easily identify how their group fits into a single party (Green et al. 2002). By contrast, cross-pressuring - being courted by multiple parties - dampens partisanship (Mutz 2002; Conroy-Krutz and Moehler 2015). For one, cross-pressuring renders individuals internally uncertain of their own positions with respect to political issues and parties, moderating political views. For two, crosspressuring renders some individuals externally (publicly) uncomfortable taking partisan sides in order to avoid social conflict. Individuals are thus incentivized to downplay partisanship publicly and reduce political participation (Moehler and Conroy-Krutz 2016).

Partisan behavioral acts and expressions (e.g., voting, rally attendance, wearing/displaying party paraphernalia) in support of a particular party facilitates a sense of commitment and loyalty to the partisan identity, as individuals seek conformity between partisan behavior, attitudes, and identity to reduce cognitive dissonance (Michelitch and Utych 2018; Brader and Tucker 2001). Lack of support towards a particular party, or support for multiple parties, by contrast, dampens partisanship (Brader and Tucker 2001).

Which groups are most effectively mobilized into loyal support and attachment to a particular political party, is, of course, context-specific. In African democracies, distributive politics largely revolves around geographic targeting of "valence" public service improvements (e.g., in health or education) to particular communities rather than redistribution among class-based groups, as well as the gifting of small handouts around election time (Bleck and van de Walle 2012). In the next subsections, we build on existing literature to argue that such distributive politics leads parties to more effectively mobilize two types of groups, increasing those groups' propensity to attach to parties: (1) coethnics of presidential or vice-presidential candidates (versus those without such a candidate), and 
(2) rural (versus urban) citizens. We then test these arguments alongside existing explanations of partisanship culled from other regions. Table 1 summarizes these hypotheses in columns one and two.

Table 1. Hypotheses and Support

\begin{tabular}{|l|c|c|}
\hline Explanatory Variable & $\begin{array}{l}\text { Hypothesized Effect } \\
\text { on Partisanship }\end{array}$ & Supported in Data? \\
\hline Rural (versus Urban) Residence & + & YES \\
\hline $\begin{array}{l}\text { Presidential and/or Vice-Presidential } \\
\text { Candidate Coethnicity }\end{array}$ & + & NO \\
\hline Electoral Cycle & U-shaped & YES \\
\hline Experience with Democracy & + & YES \\
\hline Party Entry/Exit Electoral Volatility & - & NO \\
\hline Party Age & + & NO \\
\hline Party Fractionalization & - & YES \\
\hline Age & + & YES \\
\hline Male Gender & + & YES \\
\hline $\begin{array}{l}\text { Above (versus Below) } \\
\text { Median Education }\end{array}$ & + & \\
\hline \hline
\end{tabular}

\section{Mobilization and Partisan Attachment through Candidate Coethnicity}

Seminal scholarship holds that descriptive representation of one's identity group in office motivates beliefs in enhanced substantive and symbolic representation (Pitkin 1967). Candidates may claim to represent diverse voter groups, but sharing identity with the candidate provides a credible signal that the candidate will in fact represent the group. Horowitz (2017) relates that in African politics, coethnicity with a party's presidential or vice-presidential candidate (or the equivalent in parliamentary systems) is seen as a clear and unambiguous signal of core group representation within a party. Citizens without such a candidate are more heavily crosspressured with inclusive rhetoric by multiple parties attempting to woo non-coethnics to form a winning coalition. The former hold a large degree of certainty about party fit, while the latter face more uncertainty.

Indeed, scholars of African politics have long noted that many parties emerged as ethnic group alliances and strategize to mobilize support (at least in part) along ethnic lines by courting candidates' coethnics (e.g., Ferree (2006); Posner (2005)). Citizens' beliefs are strong that parties favor their constituents in targeting public goods - coethnicity with a candidate has been shown to govern support among citizens, even 
overriding candidate competence (Carlson 2015). When citizens lack concrete information about actual targeting or other policy provision, coethnicity operates as a useful heuristic (Conroy-Krutz 2013).

Explanations abound for the success of the mutually-reinforcing relationship between citizens' support for coethnic candidates and candidates' desire to target coethnics with public goods. First, given the geographic concentration of ethnic groups, congruence in preferences for where public services should be targeted can be proxied by citizens and party leaders sharing coethnicity (Bates 1974). Second, coethnics often engage in similar economic activities and thus share similar preferences regarding public goods (Lieberman and McClendon 2012). Third, coethnics have a relatively stronger credible commitment to deliver, because they can be held accountable more readily (e.g., through shared language or denser networks) (Posner 2005). Fourth, especially among the urban poor, parties can cost-save by targeting individual handouts to coethnics (Nathan 2016). Finally, mobilization through candidate coethnicity may follow from a more expressive, symbolic-psychological mechanism activated by ethnic appeals that may play on historical group rivalries (Horowitz 1985).

However, recent literature casts doubt that candidate coethnicity with presidential and vice-presidential candidates is salient in parties' mobilization of citizens. First, perhaps little marginal value of sharing coethnicity with such candidates may exist above and beyond other signals of inclusion in the broader multiethnic coalition that a party seeks to represent. Arriola (2012) argues that parties must successfully reach across ethnic lines by offering patronage to build their party as a multiethnic coalition, especially with successive elections. Parties, for example, give, or promise to give, leaders of ethnic groups in their coalition key ministerial positions to ensure access to state resources, often ballooning the bureaucracy to do so. Through both symbolic and substantive policies that reach across ethnic lines, citizens can view parties as inclusive (Ferree and Horowitz 2010). As a result, coalitions may become so obvious that candidate coethnicity offers little marginal value in signaling party fit for the development of and maintenance of partisanship.

Second, scholars have questioned whether ethnicity is a strong enough identity to play a paramount role in party mobilization, at least as a 
generalization for the sub-continent as a whole. Koter (2013) argues that in many countries, ethnic groups are simply too large and diffuse to provide the type of effective bonds or accountability relations necessary to really draw citizens in, at least compared, often times, to the effectiveness of traditional authorities (discussed in the next section). Relatedly, heterogeneity can exist in the degree to which citizens identify with their ethnic group and see an expressive symbolic value of a coethnic candidate (Harris 2015). Yet others argue that in many contexts, ethnicity may simply be irrelevant in electoral politics (Bleck and van de Walle 2018). Prominently studied countries (e.g., Kenya, Ghana) may falsely drive a general continent-wide expectation that candidate coethnicity is important in citizen mobilization, and thus partisanship.

Third, scholars argue that parties led by non-coethnic candidates can successfully mobilize citizens out of strategic considerations in some elections. Ethnicity may only be an important heuristic absent other information, and as media environments grow stronger, citizens may encounter more information about performance (Conroy-Krutz 2013). Citizens can successfully be courted through non-coethnics' delivery of both symbolic and distributive politics (Ferree and Horowitz 2010). Additionally, strategic incentives may lead citizens to divide their loyalties - going "skirt and blouse" between parties led by coethnics and noncoethnics. For example, citizens may be mobilized for non-coethnics in legislative elections due to promises to target public goods and private handouts (Weghorst and Lindberg 2013), or because the non-coethnic candidate represents the ethnic majority group in that locality (Nathan 2016; Ichino and Nathan 2013). Such "skirt and blouse"-ism may reduce attachments to a coethnic presidential or vice-presidential candidates' party, given the inconsistency of behavioral acts with support for the coethnic party.

In sum, the scholarship provides compelling reasons for the more traditional hypothesis that coethnicity with major candidates is a key mobilizing factor that would lead to greater partisanship with a particular party. However, more recent literature also provides persuasive reasons why no such link may exist, at least as a continent-wide phenomenon. 


\section{Mobilization and Partisan Attachment Across the Rural/Urban Divide}

Scholars have pointed to several ways that party mobilization differs across the rural/urban divide, noting the presence versus lack of traditional authorities, the relative strength and diversity in the media environment, and parties' incentives to target rural areas with policy provision following multipartyism.

First, existing research underscores how urban citizens are crosspressured through individual-level mobilization by multiple parties, while traditional village authorities mediate party mobilization of rural citizens by steering them toward their preferred party. Rural villages, sometimes stemming from pre-colonial times, are commonly headed by traditional village authorities (chiefs, elders, or other "big men"), who are often paramount in day-to-day governance and household welfare, and therefore command a large degree of authority. Of course, over the continent as a whole, the nature and extent of the authority of village leadership varies across countries and villages (Koter 2013, 2016). For example, traditional authority could be relatively concentrated in the hands of a singular hereditary actor, consist of a council (e.g., of elders), shared additionally with religious or economic elites, or include formally elected individuals. However the set up, such a position often confers traditional authorities with unrivaled influence in electoral politics that lacks in urban areas. Riedl and Robinson (2016) find that such rural traditional authorities are so powerful that urban citizens, especially the many who have recently urbanized, continue to view informal authorities as those traditional authorities associated with their rural "home village" — their (or their ancestors') village of origin. Even after multiple generations of urban living, urban citizens rely on rural authorities for a range of social, economic, and religious reasons.

Scholars have suggested multiple ways in which traditional rural authorities may influence the propensity for rural citizens' to support a particular political party in word and deed (Bratton et al. 2005). Scholarship has documented that such authorities can be persuasive as opinion leaders or even act as gatekeepers - filtering and coloring information and controlling which party mobilizers enter the village - to steer villagers towards supporting their preferred political party (Bleck and Michelitch 2018; Lindberg 2010; Bleck and Michelitch 2017). Traditional authorities may only allow foot-soldiers from their preferred party into the 
village. Others emphasize that traditional authorities leverage villagers' personal loyalties to maneuver them towards supporting a particular party through coercion (Lemarchand and Legg 1972).

Yet others have shown how traditional authorities serve as intermediary vote "brokers" for parties to reduce the cost of establishing local personal ties on an individual basis with rural citizens (Koter 2013; Baldwin 2014; Lindberg 2010)). Traditional authorities have incentives to mobilize villagers to vote "en bloc" for a particular party in a quid-pro-quo exchange for public service improvements and handouts around election time, thereby increasing their own authority and welfare (Gottlieb and Larreguy 2018). Indeed, parties strategize to target those villages who effectively bloc vote (Gottlieb and Larreguy 2018) and accountability pressures for parties to give at least something to loyal rural supporters is extremely strong (Lindberg 2010). Thus, in addition to the aforementioned reasons why citizens may support the party favored by traditional authorities, citizens may strategically align with the bloc vote because they believe bloc voting will better secure public service improvements from parties (Baldwin 2013). Aligning with the bloc vote often entails expressions or acts of "public partisanship" reminiscent of rooting as a fan club as a team, which may intensify the sense of commitment and loyalty to the partisan identity, since non-conformity of such public behavior with identity may intensify cognitive dissonance (Michelitch and Utych 2018; Brader and Tucker 2001). Kuenzi and Lambright (2011) note regarding bloc voting that "Nowhere is the pressure to conform and show solidarity with the group greater than in a rural African village" (p772).

By contrast, scholarship characterizes party mobilization in urban areas very differently, as a dynamic in which citizens are approached individually and face a large degree of partisan cross-pressuring. Given the recent and rapid urbanization across the continent, urban areas where people live, work, and shop are highly diverse on ethnic and partisan lines, including intermarriage (Dulani et al. 2018). Urban areas tend to be competitive between multiple parties, which try to compete for citizens on an individual-level, short-term basis - especially the urban poor, which constitutes by far the largest swath of urban citizens (Resnick 2012; Lindberg 2010). Since parties lack capacity to forge long-term clientelistic relations on an individual basis (Bratton et al. 2005), they tend to engage in strategies that include flooding the urban poor with handouts and gifts. 
Citizens often readily accept small gifts from multiple parties in what is called "harvesting season" with little to no reciprocal loyalty to the parties (Lindberg 2010).

A second reason why rural citizens may be more likely to be partisan than urban citizens relates to the differences in the mass media environment across rural and urban areas. Mass media has historically been limited to major, usually coastal capitol, cities in Africa (Hyden et al. 2003; Bourgault 1995). Especially since the early 1990s, mass media in urban areas has been characterized as rich and diverse with multiple radio stations serving differing partisan slants, which are blasted loudly and publicly on public transport and from shops and dwellings (Conroy-Krutz and Moehler 2015; Moehler and Singh 2011). By contrast, exposure to mass media in rural areas is much more limited - recently foreign aid organizations have sought to expand access to radio (e.g., state broadcasting) into rural areas and some remote areas still do not have access (Bleck and Michelitch 2017). Otherwise, rural areas may have access to community radio that serves the local population on community issues, which is often staffed by volunteers who speak in local dialects and only in partial operation; these stations largely reinforce the partisan slant of the community (Bourgault 1995). Traditional authorities can further shape the impact of radio content towards a favorite party - where radios or batteries are scarce due to poverty, traditional authorities may stage listening groups where they publicly interpret and evaluate the content (Bleck and Michelitch 2017). In sum, urban citizens tend to receive cross-pressuring partisan signals in a rich and diverse media environment, while rural citizens often have access to much more limited mass media containing partisan-reinforcing signals.

A final group of scholars underscore how the introduction of competitive multiparty elections incentivizes parties to pursue policies that primarily benefit the interests of large rural majorities (Bates and Block 2013; Harding 2018; Bratton et al. 2005; Kuenzi and Lambright 2011). Even without liaising with traditional authorities as brokers, parties may find it easier to court rural citizens because their communities can be more clearly geographically-targeted with public service delivery to foster an accountability relationship. By contrast, urban citizens constantly move across neighborhoods using infrastructure and public services and cannot be exclusively targeted (Ichino and Nathan 2013). Further, the provision of 
public services can be pro-rural due to programmatic forms of distribution - e.g., the benefits of formally universal policies such as free health insurance and schooling often accrue primarily to rural citizens (Harding 2018).

Taken together, these mechanisms underscore that rural citizens are often mobilized towards a particular political party through traditional authorities' influence (as opinion leaders, or brokers), a weaker media environment, and more efficacious targeting of policy. By contrast, urban citizens tend to be directly cross-pressured at the individual-level by parties and media, and it is much more difficult for parties to establish loyal supporters because they are simply harder to target effectively. Thus, we hypothesize that partisanship should be higher among rural citizens.

\section{Research Design}

We leverage a variety of data sources to test our argument alongside existing explanations. Table 1 summarizes the hypotheses and data sources used for variable operationalization. See SI B for descriptive statistics.

\section{Outcome and Primary Explanatory Variables}

Partisanship: We code an indicator variable for whether respondents "feel close to any particular political party" from Afrobarometer Data Rounds 1-6 (over 180,000 respondents across 30 countries). Crossnational variation within Africa is stark, ranging from $29 \%$ to $83 \%$. See SI $\mathrm{B}$ for a list of countries included in each round.

Rural: We code an indicator variable for rural (versus urban) residence defined in Afrobarometer in their survey sampling frames, which are constructed from the most recent national population census data in each country.

Coethnic Candidate: We code the ethnicity of winning and losing presidential and vice-presidential candidates, or the equivalent in parliamentary systems (see SI E for coding details). We code the indicator variable Coethnic Candidate as one if an individual had a coethnic incumbent or opposition presidential or vice-presidential candidate in the upcoming election for respondents surveyed in the final year of the electoral cycle, and for all other respondents we code the variable as one if they had a coethnic incumbent or opposition presidential or vicepresidential candidate in the previous elections. Extensive care has been 
taken over the coding of coethnicity in each country, but because Afrobarometer coding is often not as fine-grained as ideal, and some countries might hold anomalies, we have checked that any results are robust to sequentially dropping each country from the analysis. Our codings are joining forces with additional coauthors to create a larger forthcoming dataset called the African Leader and Candidate Ethnicity Dataset (Adida et al. 2020).

\section{Variables Testing Existing Explanations}

We briefly summarize existing determinants of partisanship in new democracies.

Electoral Cycle: Given cyclical fluctuations in the degree of citizen mobilization, Michelitch and Utych (2018) argue that partisanship strengthens during election season due to increased exposure to partisan political information and higher net benefit from political participation around elections. Across 86 countries, they find that the probability of partisanship rises 6 percentage points from cycle midpoint to an election, with larger effects in low-income countries. We extend their data forward in time and likewise operationalize the electoral cycle as the percentage of time that has passed at the time of the survey between the last and next election. Because the hypothesized relationship is quadratic, this variable and its square are included.

Experience with Democracy: Repeated multiparty elections habituate citizens to politically participating and encourage them to take a stake in electoral outcomes, thereby facilitating and mutually-reinforcing attachments to a party (Brader and Tucker 2008; Lupu 2015). Conversely, when disruptions to regular elections occur (e.g., through military coup), citizens experience a break in this process and perceive partisanship as futile in an unstable political environment. Przeworski (2013)'s Political Institutions and Political Events (PIPEs) dataset contains country-year data covering all countries from independence until 2008, which we extended to 2015 (See SI C). We operationalize experience with multiparty democracy at the individual-level as the number of continuous multiparty years an individual has experienced since adulthood.

Electoral Volatility: (Lupu 2013) argues that party system institutionalization stabilizes the choice set of parties from which individuals must choose, facilitating partisanship. We extend Weghorst and Bernhard 
(2014)'s dataset forward in time, which measures party entry/exit volatility (See SI D).

Party Age: When parties are well-established, their reputations become more widely known, facilitating partisanship (e.g., Dalton and Weldon (2007)). We use the Database of Political Institutions (DPI) (Cruz et al. 2018), which calculates the average age of the largest two government parties and the largest opposition party, or the relevant subset of these for which age of party is known.

Party Fractionalization: As the number of parties increases, the party landscape becomes more complex to navigate, which scholars argue reduces partisanship (e.g., Lupu (2015)). We use the probability that two legislators picked at random will be from different parties from the DPI (Cruz et al. 2018).

Age: Older people are more likely to be partisan, given they have more time and social mandate to engage in politics. Age is a continuous variable from the Afrobarometer.

Male Gender: The traditional division of labor holds that men operate in the public, and women the private, sphere, which generally reduces women's political engagement (Bleck and Michelitch 2018). Men have more free time and collective forums for political discussion and participation (e.g. baraza, grin), while women often face more work in and outside the home. We code an indicator variable for male gender from Afrobarometer.

Education: Education (ranging from none, to primary, to secondary, to a few tertiary in the Afrobarometer) grants fluency in the language of government and civics training, which lower costs of accessing and processing political information, facilitating political participation and partisanship. We code whether respondents are above median education level in their country (for each country-round).

\section{Results}

We examine the determinants of individuals' partisanship. Having multiple surveys for each country over time allows us to leverage temporal variation in country-level factors. We thus estimate linear probability models with country and survey round fixed effects and standard errors clustered by survey-round. We deal with missingness by assigning the variable mean and adding an indicator variable to indicate missing status 
Table 2. Determinants of Partisanship in Africa

\begin{tabular}{|c|c|c|c|c|c|}
\hline$D V=$ Partisanship & (1) & (2) & (3) & (4) & (5) \\
\hline Rural & $\begin{array}{c}0.0746^{* *} \\
(0.0055)\end{array}$ & $\begin{array}{l}0.0741^{* *} \\
(0.0055)\end{array}$ & $\begin{array}{c}0.0755^{* *} \\
(0.0053)\end{array}$ & $\begin{array}{l}0.0748^{* *} \\
(0.0054)\end{array}$ & $\begin{array}{l}0.0754^{* *} \\
(0.0051)\end{array}$ \\
\hline Coethnic Candidate & $\begin{array}{l}-0.0072 \\
(0.0082)\end{array}$ & $\begin{array}{l}-0.0076 \\
(0.0081)\end{array}$ & $\begin{array}{l}-0.0082 \\
(0.0084)\end{array}$ & $\begin{array}{l}-0.0042 \\
(0.0082)\end{array}$ & $\begin{array}{l}-0.0067 \\
(0.0084)\end{array}$ \\
\hline Age & $\begin{array}{l}0.0016^{* *} \\
(0.0002)\end{array}$ & $\begin{array}{c}0.0007^{* *} \\
(0.0002)\end{array}$ & $\begin{array}{c}0.0016^{* *} \\
(0.0002)\end{array}$ & $\begin{array}{l}0.0016^{* *} \\
(0.0002)\end{array}$ & $\begin{array}{l}0.0006^{*} \\
(0.0002)\end{array}$ \\
\hline Male & $\begin{array}{c}0.0738^{* *} \\
(0.0059)\end{array}$ & $\begin{array}{c}0.0746^{* *} \\
(0.0059)\end{array}$ & $\begin{array}{c}0.0735^{* *} \\
(0.0059)\end{array}$ & $\begin{array}{l}0.0739^{* *} \\
(0.0059)\end{array}$ & $\begin{array}{l}0.0742^{* *} \\
(0.0059)\end{array}$ \\
\hline Educated & $\begin{array}{l}0.0128^{\dagger} \\
(0.0065)\end{array}$ & $\begin{array}{l}0.0143^{*} \\
(0.0066)\end{array}$ & $\begin{array}{c}0.0157^{* *} \\
(0.0059)\end{array}$ & $\begin{array}{l}0.0133^{*} \\
(0.0065)\end{array}$ & $\begin{array}{l}0.0186^{* *} \\
(0.0058)\end{array}$ \\
\hline Experience with Democracy & & $\begin{array}{l}0.0033^{* *} \\
(0.0006)\end{array}$ & & & $\begin{array}{l}0.0037^{* *} \\
(0.0006)\end{array}$ \\
\hline Electoral Volatility & & & $\begin{array}{l}-0.0004 \\
(0.0007)\end{array}$ & & $\begin{array}{c}0.0000 \\
(0.0006)\end{array}$ \\
\hline Party Age & & & $\begin{array}{c}-0.0008 \\
(0.0013)\end{array}$ & & $\begin{array}{c}-0.0008 \\
(0.0012)\end{array}$ \\
\hline Party Fractionalization & & & $\begin{array}{l}-0.0408 \\
(0.0501)\end{array}$ & & $\begin{array}{l}-0.0439 \\
(0.0477)\end{array}$ \\
\hline Electoral Cycle & & & & $\begin{array}{l}-0.0052 \\
(0.1223)\end{array}$ & $\begin{array}{l}-0.1787 \\
(0.1216)\end{array}$ \\
\hline Electoral Cycle ${ }^{2}$ & & & & $\begin{array}{c}0.0734 \\
(0.1103)\end{array}$ & $\begin{array}{l}0.2206^{\dagger} \\
(0.1134)\end{array}$ \\
\hline Observations & 180091 & 180091 & 180091 & 180091 & 180091 \\
\hline Number of countries & 30 & 30 & 30 & 30 & 30 \\
\hline
\end{tabular}

Note: Linear probability models with country and year fixed effects, survey-clustered standard errors in parentheses.

$\dagger \mathrm{p}<.1,{ }^{*} \mathrm{p}<.05,{ }^{* *} \mathrm{p}<.01$.

on a particular observation for the particular variable. See SI F for a discussion of these choices.

The empirical results are presented in Table 2, while Table 1 summarizes hypothesis support in column three. First, the results demonstrate that citizens in rural areas are significantly more likely to be partisan than urban citizens, a result robust to a range of specifications. The effect is substantively large - rural citizens are almost 8 percentage points more likely than urban citizens to be partisan. Second, sharing coethnicity with major national election candidates does not appear to make citizens any more likely to be partisan than those citizens who do not share coethnicity with any such candidates.

The results also support some existing explanations of partisanship in new democracies in other regions. The likelihood of partisanship increases by one percentage point for each additional three years of experience 
that an individual has with multiparty democracy after the age of 18 , underscoring the finding that experience with democracy is associated with partisanship found in both Latin America and Eastern Europe (Brader and Tucker 2008; Lupu 2015). As expected and consistent with elsewhere, older, male, and educated citizens are more likely to be partisan. Finally, support exists for the $U$ shaped electoral cycle effect, consistent with global estimates (Michelitch and Utych 2018); this is demonstrated in a plot of predictive margins of partisanship over the electoral cycle (see SI F.5). Interestingly, we find that none of the variables capturing party system institutionalization are significantly correlated with partisanship, unlike other regions (Dalton and Weldon 2007; Lupu 2015, 2013).

In SI F, we show results are robust to: (1) list-wise deletion for missingness, (2) other model specifications (alternative education operationalization, logistic regression, random effects, mixed-effects maximum likelihood regression with random intercepts and random slopes), and (3) additional control variables (dominant party system, party strength, beliefs about the enumerator's organization, strength of traditional leader influence, receipt of handouts, media exposure, poverty index, assets index, perceptions of election quality, and contact with parties and members of parliament). SI F.4. lists by-country regressions for interested country specialists.

\section{Robustness and Extensions of Candidate Coethnicity}

To interrogate the null result between candidate coethnicity and partisanship more thoroughly, we undertake two types of analyses. First, we rerun all models using the following alternative codings of candidate coethnicity: (a) coethnicity based on the identity of the candidates in the prior election (regardless of the time point in the electoral cycle), (b) coethnicity only with party flagbearers, not running mates, (c) coethnicity only with the incumbent, and (d) examining (a), (b) and (c) based on living in the candidate's birth region, which some might argue offers a better measurement of ethnicity. We find no evidence of a relationship (see SI G.1). Examining by-country regression results we see mostly a null relationship (see SI F.4). ${ }^{2}$

Second, we investigate the following country-level moderators that may yield country-level heterogeneity in the relationship, but find no evidence: (i) experience with democracy, (ii) urban/rural, (iii) ethnic group structure 
(multiple measures), (iv) electoral cycle, (v) dominant party presence. See SI G.2 for theoretical motivation and regression results.

In sum, these results do not support the idea that candidate coethnicity facilitates partisanship. We recognize that there may be other ways that parties could use coethnicity to mobilize support aside from candidate coethnicity, such as diverse types of ethnic appeals made during campaigns (Gadjanova 2015).

\section{Rural/Urban Extension}

We examine an observable implications of one mechanism stated in the rural-urban divide argument. According to our argument, partisanship can be facilitated by traditional authorities' influence and/or brokering role for bloc voting, steering citizens to support a particular party and engendering and reinforcing partisanship. If connections to traditional authorities encourages partisanship, we should see that those with more trust in and contact with such authorities (questions available on the Afrobarometer) should be more likely to be partisan. This relationship should hold for both rural and urban citizens, recalling that some urban citizens often remain connected to traditional authorities in their "home village" (Riedl and Robinson 2016).

We thus re-estimate the model in column 1 of Table 2, adding in the variables Contact with Traditional Leaders and Trust in Traditional Leaders and interaction terms between these and the Rural variable in order to evaluate whether the effect of trust and contact on partisanship is conditional on rural-urban residence. Results are displayed graphically in Panels (a) and (b) of Figure 2, which plot the predictive margins of Rural by trust in and contact with traditional leaders, respectively. Consistent with this part of our argument, those having greater trust in or higher rates of contacting such leaders are more likely to be partisan among both rural and urban citizens. Interestingly, among citizens without closeness to traditional authorities, rural citizens are much more partisan than urban citizens - perhaps due to other mechanisms we suggested that lower partisanship in urban areas - e.g., media cross-pressuring and individuallevel targeting of small gifts by multiple parties. This analysis is robust to creating an index of persuasiveness (see SI H for question wording and regression results). 


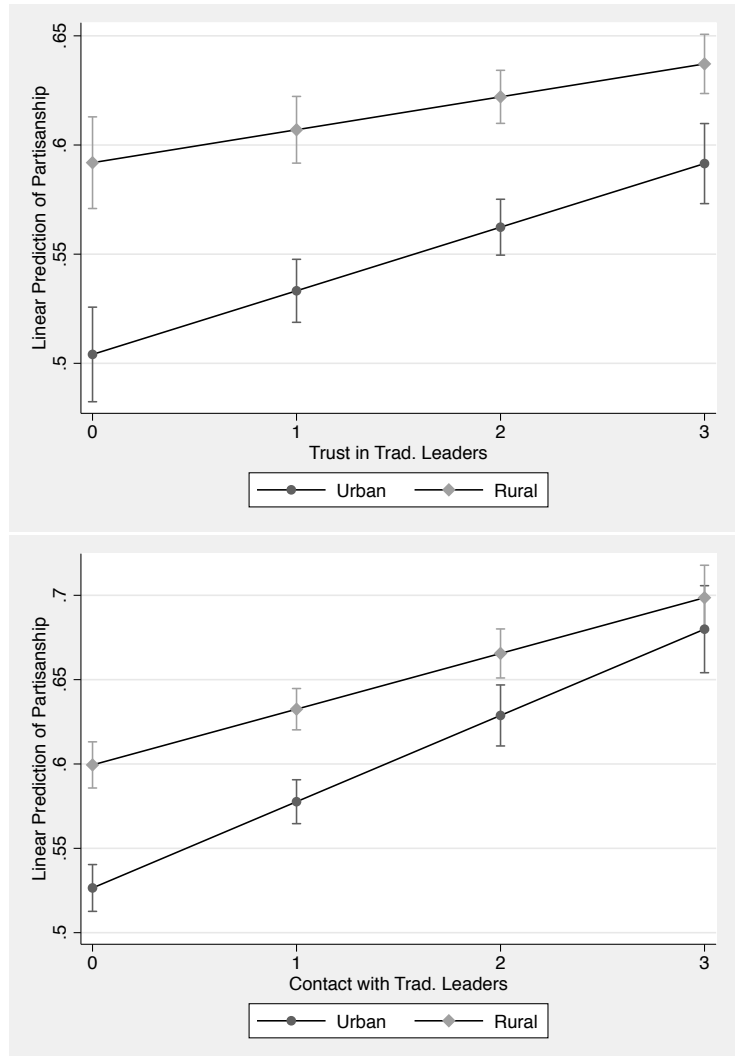

Figure 2. Closeness with traditional authorities and partisanship. Predictive margins with $95 \%$ confidence intervals of trust in (top panel) and contact with (bottom panel) traditional authority on partisanship.

\section{Is Partisanship Meaningful in Africa?}

Is Africans' partisanship an "empty label" or a meaningful identity? Although we have demonstrated that partisanship is high in Africa and governed by important demographic, institutional, electoral cycle, and party mobilization factors, some scholars may wonder whether it is superficial - merely an indicator of affiliation with a spoils coalition (Moehler et al. 2011) or a casual opportunity for patronage (Bratton et al. 2012). One way scholars in Latin America and Eastern Europe have demonstrated that partisanship is a meaningful identity is to examine whether a positive relationship exists between partisanship and diverse acts of political and civic participation (Lupu 2015; Brader and Tucker 


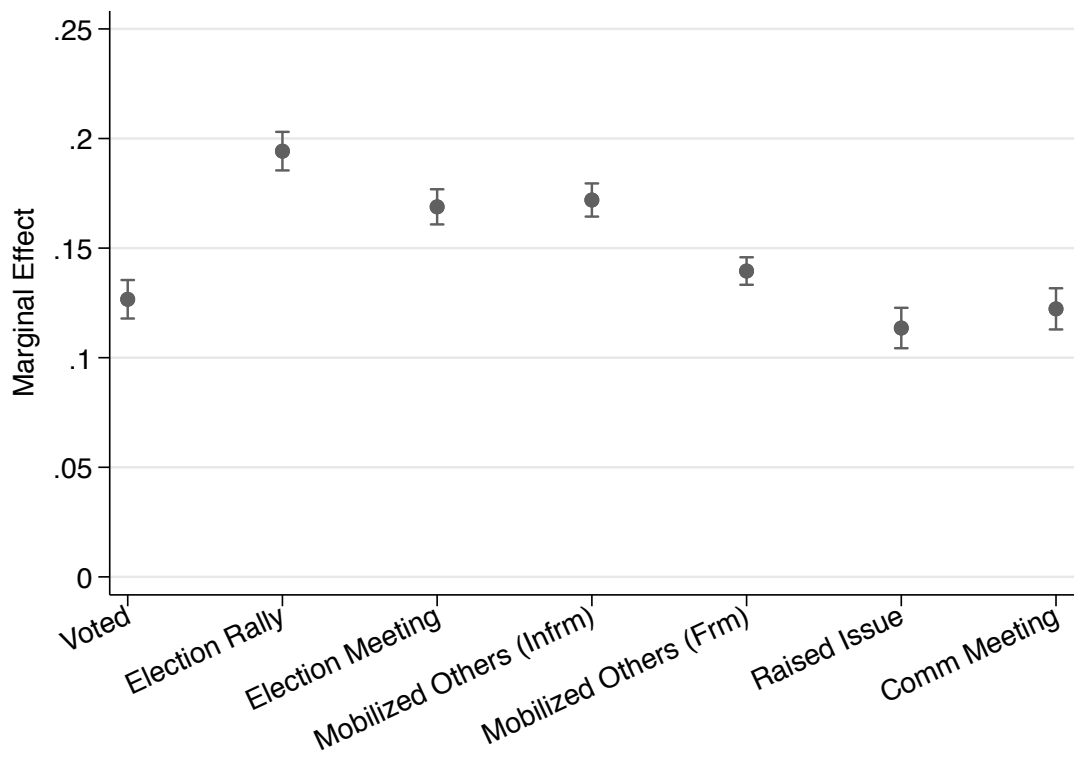

Figure 3. Marginal effect of partisanship on political participation from logistic regressions using Afrobarometer Round 6.

2001). Since the third wave of democracy started in the 1990s, political participation has been cited as extremely important and consequential in the context of democratization, yet highly variable within and across African countries (Bratton et al. 2005).

Regressing forms of political behavior on partisanship using the latest round of Afrobarometer data - see Figure 3, partisanship indeed appears to be highly correlated with political behavior in Africa, as elsewhere. Partisans across Africa are 12 percentage points more likely to vote (dovetailing Kuenzi and Lambright (2011)'s findings), 20 percentage points more likely to have attended an election rally, 16 percentage points more likely to have attended a pre-election party meeting, 18 percentage points more likely to have informally mobilized others to vote for a particular party (14 for formal mobilization), 11 percentage points more likely to raise an issue to an authority, and 12 percentage points more likely to have attended community meetings. We interpret these findings as associative rather than causal, given that partisan attachments mutuallyreinforce such acts of participation. Results are robust when including 
rural/urban, age, gender, poverty index, asset index, and education in regressions. See SI I for descriptive statistics and regression tables.

We conclude from this final analysis that discovering the determinants of partisanship in Africa is not pre-mature. Demonstrating that partisanship is so highly associated with diverse acts of political participation underscores the importance of knowing why some groups are more likely to be partisan. This study joins others in contending that partisan attachments are meaningful in Africa, demonstrating partisan ingroup/outgroup discrimination (Michelitch 2015), cuing for vote choice (Conroy-Krutz et al. 2016), motivated reasoning (Adida et al. 2017), and attribution bias (Carlson 2016).

\section{Conclusion}

Public opinion data reveals that partisanship is quite high in Africa, compared to other regions. Why do some citizens in such new democracies attach to parties while others do not? This study examines two arguments related to parties' group mobilization tactics, alongside existing explanations, across 30 African countries.

First, we evaluate the influence of coethnicity with major party leaders - the president or vice-presidential candidate — on partisanship. According to traditional wisdom, when citizens observe coethnic party leaders, they receive strong signals of fit with the party and expect better representation, strengthening partisanship. Indeed, ethnicity is often described as the dominant axis for electoral politics. However, the data do not show cross-national evidence that citizens are more likely to be partisan if they share coethnicity with such candidates, and moreover, no consistent relationship conditional on theoretically-driven moderators.

This (non-)finding supports contemporary work questioning the importance of candidate coethnicity. Scholars have argued that coethnicity with party flagbearers is a weak marginal signal of representation above and beyond other signals of inclusion - other ethnic coalition partners within the party are represented visibly in other leadership positions (e.g., minister positions) and/or otherwise successfully wooed in campaigns. Others question the importance of candidate coethnicity for generating party support per se - in many contexts ethnicity may be too diffuse of an identity group to effectively rally citizens, or does not constitute an important political cleavage, or citizens face other strategic considerations 
pulling them away from parties with coethnic flagbearers. Perhaps scholars have falsely over-generalized the importance of candidate coethnicity from prominently-studied cases where the relationship exists (e.g., Ghana, Kenya).

Second, by contrast to the seminal literature from Western Europe that emphasizes the early growth of mass partisan mobilization among class-based groups in urban areas, we find that parties in Africa more effectively mobilize loyal support from rural citizens. While urban citizens are heavily cross-pressured by multiple parties and a diverse media on an individual basis, rural citizens are often steered towards a particular political party by traditional authorities, a weaker media environment, and more efficacious targeting of public goods. Indeed, we find supportive evidence for observable implications of part of our argument: those with closer ties to traditional authorities are more likely to be partisan.

We further find support for some, but not all, theories of partisanship from other regions with new democracies. While basic demographic, electoral cycle, and experience with democracy patterns hold, party system explanation do not. One reason may be that party system changes are more salient for partisanship where party competition largely revolves around class-based redistribution, as in Eastern Europe or Latin America, because citizens may have more difficulty finding fit with repositioning parties along an ideological spectrum. A second reason is that perhaps the data overestimate the level of party system newness or change in Africa. Some parties might change names but the leaders of the parties may persist and carry their following. Some leaders (or political family dynasties) have roots that go back to independence movements, or autocratic single parties that pre-date the multiparty era.

Discovering which groups are more likely to be partisan is important because it affects participation in politics, attitude formation, and even treatment of other citizens. Future research on partisanship in new democracies should consider the role of party mobilization tactics that target certain groups of citizens. Which groups are mobilized is likely to be context specific, and comparativists must draw on contextual knowledge to localize the theory moving forward. 


\section{Acknowledgements}

We would like to acknowledge Nicolas van de Walle, Elias Dinas, Tariq Thachil, Noam Lupu, Elizabeth Zechmeister, Keith Weghorst, Amanda Clayton, Cindy Kam, Alan Wiseman, Larry Bartels, Lisa Mueller and participants at the 2018 AWESOME conference at New York University, the 2018 American Political Science Association panel, the 2017 UK Working Group on African Political Economy at Oxford, and the 2018 European Union Institute SPS Seminar Series. We thank SangEun Kim, Seung Yeon Kim, and Friederike Haberstroh for research assistance.

\section{Declaration of conflicting interests}

We have no conflicts of interest.

\section{Funding}

This publication was made possible in part by a grant from Carnegie Corporation of New York. The statements made and views expressed are solely the responsibility of the author.

\section{Supplemental material}

The online supplemental information, datasets and do files are available at ..

\section{Notes}

1. Consistent with Ishiyama and Fox (2006), who test whether demographic characteristics notable in other regions are associated with partisanship in 12 African countries using Afrobarometer R1.

2. A null relationship exists in 14 countries, a positive relationship in 6 countries, and a negative relationship in 8 countries. Ghana and Kenya, commonly studied cases, are two of six cases where the relationship holds.

\section{References}

Adida C, Combes N, Harding R and Michelitch K (2020) African leader and candidate ethnicity. Original Dataset in Progress .

Adida C, Gottlieb J, Kramon E, McClendon G et al. (2017) Reducing or reinforcing in-group preferences? an experiment on information and ethnic voting. Quarterly Journal of Political Science 12(4): 437-477.

Arriola LR (2012) Multi-ethnic Coalitions in Africa: business financing of opposition election campaigns. Cambridge University Press.

Baldwin K (2013) Why vote with the chief? political connections and public goods provision in zambia. American Journal of Political Science 57(4): 794-809.

Baldwin K (2014) When politicians cede control of resources: Land, chiefs, and coalition-building in africa. Comparative Politics 46(3): 253-271. 
Bates RH (1974) Ethnic competition and modernization in contemporary africa. Comparative Political Studies 6(4): 457-484.

Bates RH and Block SA (2013) Revisiting african agriculture: Institutional change and productivity growth. The Journal of Politics 75(2): 372-384.

Bleck J and Michelitch K (2017) Capturing the airwaves, capturing the nation? a field experiment on state-run media effects in the wake of a coup. The Journal of Politics 79(3): 873-889.

Bleck J and Michelitch K (2018) Is women's empowerment associated with political knowledge and opinions? evidence from rural mali. World Development 106: 299-323.

Bleck J and van de Walle N (2012) Valence issues in african elections: Navigating uncertainty and the weight of the past. Comparative Political Studies 46(11): 1394-1421.

Bleck J and van de Walle N (2018) Electoral Politics in Africa since 1990. Cambridge University Press.

Bourgault LM (1995) Mass media in sub-Saharan Africa. Indiana University Press.

Brader T and Tucker J (2001) The emergence of mass partisanship in russia, 1993-1996. American Journal of Political Science 45(1): 69-83.

Brader T and Tucker J (2008) Pathways to partisanship: Evidence from russia. Post-Soviet Affairs 24(3): 263-300.

Bratton M, Bhavnani R and Chen TH (2012) Voting intentions in africa: ethnic, economic or partisan? Commonwealth \& Comparative Politics 50(1): 27-52.

Bratton M, Mattes R and Gyimah-Boadi E (2005) Public opinion, democracy, and market reform in Africa. Cambridge University Press.

Carlson E (2015) Ethnic Voting and Accountability in Africa: A Choice Experiment in Uganda. World Politics 67(2): 353-385.

Carlson E (2016) Finding partisanship where we least expect it: Evidence of partisan bias in a new african democracy. Political Behavior 38(1): 129-154.

Conroy-Krutz J (2013) Information and ethnic politics in africa. British Journal of Political Science 43(02): 345-373.

Conroy-Krutz J and Moehler DC (2015) Moderation from bias: A field experiment on partisan media in a new democracy. The Journal of Politics 77(2): 575-587.

Conroy-Krutz J, Moehler DC and Aguilar R (2016) Partisan cues and vote choice in new multiparty systems. Comparative Political Studies 49(1): 3-35.

Cruz C, Keefer P and Scartascini C (2018) Database of political institutions 2017 (dpi2017). InterAmerican Development Bank. Numbers for Development .

Dalton R and Weldon S (2007) Partisanship and party system institutionalization. Party Politics 13: 179.

Dulani B, Harris A, Horowitz J and Kayuni H (2018) Intermarriage, ethnic mixing, and ethnic voting in africa. Midwestern Political Science Conference Paper.

Ferree K (2006) Explaining south africa's racial census. Journal of Politics 68(3): 803-15.

Ferree K and Horowitz J (2010) Ties that bind? the rise and decline of ethno-regional partisanship in malawi, 1994-2009. Democratization 17(3): 534-563.

Gadjanova E (2015) Measuring parties' ethnic appeals in democracies. Party Politics 21(2): 309327. 
Gottlieb J and Larreguy H (2018) An informational theory of electoral of electoral targeting in young clientelistic democracies: Evidence from senegal. Berkeley Center on the Politics of Development Working Paper 2016(15).

Green D, Palmquist B and Schickler E (2002) Partisan Hearts and Minds. New Haven: Yale University Press.

Harding R (2018) Rural Democracy: Elections and Development in Africa. Manuscript.

Harris AS (2015) When Voting is not Black and White: Ethnic Proximity and Voter Preferences. PhD Thesis, New York University.

Horowitz D (1985) Ethnic Groups in Conflict. University of California Press.

Horowitz J (2017) Ethnicity and the swing vote in africa's emerging democracies: Evidence from kenya. British Journal of Political Science : 1-21.

Huntington SP (1968) Political Order and Changing Societies. New Haven, CT: Yale University Press.

Hyden G, Leslie M and Ogundimu F (eds.) (2003) Media and Democracy in Africa. Transaction.

Ichino N and Nathan NL (2013) Crossing the line: Local ethnic geography and voting in ghana. American Political Science Review 107(2): 344-361.

Ishiyama J and Fox C (2006) What affects the strength of partisan identity in sub-saharan africa. Politics and Policy 34(4): 748-773.

Koter D (2013) King makers: Local leaders and ethnic politics in africa. World Politics 65(2): $187-232$.

Koter D (2016) Beyond ethnic politics in Africa. Cambridge University Press.

Kuenzi M and Lambright GM (2011) Who votes in africa? an examination of electoral participation in 10 african countries. Party Politics 17(6): 767-799.

Lemarchand R and Legg K (1972) Political clientelism and development: a preliminary analysis. Comparative politics 4(2): 149-178.

Lieberman ES and McClendon GH (2012) The ethnicity?policy preference link in sub-saharan africa. Comparative Political Studies 56(5): 574-602.

Lindberg S (2010) What accountability pressures do mps in africa face and how do they respond? evidence from ghana. Journal of Modern African Studies 48(1): 117-142.

Lipset SM and Rokkan S (1967) Party Systems and Voter Alignments: Cross-National Perspectives. New York: The Free Press.

Lupu N (2013) Party brands and partisanship: Theory with evidence from a survey experiment in argentina. American Journal of Political Science 57(1): 49-64.

Lupu N (2015) Partisanship in latin america. The Latin American voter: Pursuing representation and accountability in challenging contexts : 226-245.

Michelitch K (2015) Does electoral competition exacerbate interethnic or interpartisan discrimination? evidence from a market price bargaining experiment. American Political Science Review 109(1): 43-61.

Michelitch K and Utych S (2018) Electoral cycle fluctuations in partisanship: Global evidence from eighty-six countries. The Journal of Politics 80(2): 412-427.

Moehler DC and Conroy-Krutz J (2016) Partisan media and engagement: A field experiment in a newly liberalized system. Political Communication 33(3): 414-432. 
Moehler DC, Conroy-Krutz J and Pariente RA (2011) Parties on the ballot: Cues and voting behavior in a new party system. Experiments in Governance and Politics, MIT .

Moehler DC and Singh N (2011) Whose news do you trust? explaining trust in private versus public media in africa. Political Research Quarterly 64(2): 276-292.

Mutz DC (2002) The consequences of cross-cutting networks for political participation. American Journal of Political Science : 838-855.

Nathan NL (2016) Local ethnic geography, expectations of favoritism, and voting in urban ghana. Comparative Political Studies 49(14): 1896-1929.

Pitkin H (1967) The Concept of Political Representation. University of California Press.

Posner D (2005) Institutions and Ethnic Politics in Africa. Cambridge University Press.

Przeworski A (2013) Political institutions and political events (pipe) data set. Department of Politics, New York University .

Resnick D (2012) Opposition parties and the urban poor in african democracies. Comparative Political Studies 45(11): 1351-1378.

Riedl RB and Robinson AL (2016) Who is an urban citizen? the nature of urban-rural linkages among urban kenyans. Presented at the Midwestern Group for African Political Economy .

Weghorst K and Bernhard M (2014) From formlessness to structure? the institutionalization of competitive party systems in africa. Comparative Political Studies 47(12): 1707-1737.

Weghorst K and Lindberg S (2013) What drives the swing voter in africa? American Journal of Political Science 57(3): 717-734.

\section{Author biography}

Kristin Michelitch is an Andrew Carnegie Fellow and Assistant Professor in Vanderbilt University's Political Science Department.

Robin Harding is an Associate Professor in Oxford University's Government Department in Lady Margaret Hall College. 